\title{
The Mineral Trioxide Aggregate in Vital Pulp Therapy of Permanent Teeth - A Systematic Review
}

\author{
Manoj Chandak ${ }^{1}$, Madhulika Shyam Sundar Chandak², Chanchal Harikishor Rathi ${ }^{3}$, Pooja Chandak ${ }^{4}$ Kajol Relan ${ }^{5}$ \\ 1, 2, 3, 4, 5 Department of Conservative Dentistry and Endodontic, Sharad Power Dental College, \\ Sawangi, Wardha, Maharashtra, India.
}

\section{ABSTRACT}

\section{BACKGROUND}

Dental pulp is living tissue, and its vitality is the most important factor for long sterm survival of teeth. Pulp is the main organ of teeth which helps in the formation of dentin. Vital pulp therapy brings a great advancement in the treatment of diseased pulp that does not have periapical pathology. It is the choice of treatment in many conditions before the shift towards root canal treatment. The improvement in material part and concept of bioactive materials shows higher success rate. Vital pulp therapy is the treatment which mainly aims to preserve and maintain pulp tissue that has been compromised but not destroyed due to caries, mechanical trauma, or other restorative procedures. Vital pulp therapy is mainly recommended in young patients due to high immune activity to regenerate the pulp vitality, apical root growth formation etc. As far as the masticatory forces applied during chewing are concerned, the vital teeth are highly resistant to these forces than root filled teeth. Many materials are used for these procedures such as calcium hydroxide, MTA, Biodentine, etc. In this review we compared the MTA used in various vital pulp therapy procedures with other materials. MTA is a superior material and brings about early differentiation of odontoblast cells and helps in the formation dentin bridge. It has been said that activity of dental pulp cells increases when it come in contact with MTA.

Clinical success rate of vital pulp therapy depends on the histologic findings such as thickness of dentin barrier and formation of reparative dentin. Absence of clinical symptoms with long term follow up is the most important criterion. ${ }^{3}$

\section{KEY WORDS}

MTA, Vital Pulp Therapy, $\mathrm{Ca}(\mathrm{OH})_{2}$, Direct Pulp Capping

\section{Corresponding Author:}

Dr. Madhulika Shyam Sundar Chandak, Department of Conservative Dentistry and Endodontic, MDS Sharad Power Dental College, Sawangi, Wardha, Maharashtra, India.

E-mail: chandakmadhulika40@gmail.com

DOI: $10.14260 /$ jemds $/ 2021 / 7$

How to Cite This Article:

Chandak M, Chandak MS, Rathi CH, et al. The mta in vital pulp therapy of permanent teeth: a systematic review. J Evolution Med Dent Sci 2021;10(01):34-38, DOI: 10.14260/jemds/2021/7

Submission 03-06-2020,

Peer Review 10-10-2020,

Acceptance 16-10-2020,

Published 04-01-2021.

Copyright (C) 2021 JEMDS. This is an open access article distributed under Creative Commons Attribution License [Attribution 4.0 International (CC BY 4.0)] 


\section{BACKGROUND}

Globally, the most prevalent disease in permanent teeth is decayed teeth, if remained untreated, exposure of pulp may occur due to caries or mechanical trauma. It may undergo pathological changes such as inflammation, which invariably result in irreversible pulpitis and necrosis of teeth. Preservation of the vitality of tooth is important for maintaining the normal health and function of teeth. ${ }^{1}$ "Vital pulp therapy" is termed as a clinical procedure which aims to preserve and retain the pulp tissue that has been compromised but not destroyed by caries, trauma, restorative techniques and is in a healthy state. This procedure is suggested in early aged patients than the older patients due to more healing and regenerative ability of pulp tissue in early aged patients. Another benefit of this procedure is productive confrontation to masticatory forces compared to root filled teeth. In most of deep carious lesions, inflammation is restricted to superficial pulp. Radicular pulp tissue remains normal, except for some dilated blood vessels. It has been claimed that pulp healing is possible even after a carious exposure. $^{2}$

Vital pulp therapy mainly includes indirect pulp-capping, direct pulp-capping, apexogenesis, apexification and partial pulpotomy. The material used in this procedure to cover exposed pulp should be biocompatible in nature. The main goal of this treatment is to protect the primary cells of pulp i.e. odontoblasts and formation of reactionary and reparative dentin at the pulp-dentin complex, and also to promote remineralization of existing dentin to support the pulp-dentin complex. ${ }^{1}$ From many years calcium hydroxide is the material of choice in clinical practice for vital pulp therapy. It is gold standard material. It has many advantages like antimicrobial effect due to high alkaline $\mathrm{pH}$, and stimulate the pulpal tissue that helps in pulpal defence and repair. Although the calcium hydroxide apexification shows high success rate, the time required to complete the treatment is 15 months, which is undesirable. Though it is gold standard material till date, there are many drawbacks of calcium hydroxide such as occurrence of tunnels in dentin bridge, pulp space obliteration, increased solubility in oral fluids, reduced sealing capacity and deprivation over time. The risk of root-fracture in long term use is reported. All this has led to recent advancements in biomaterials. It has been developed with significant improvement in the success rate of various vital pulp treatment in permanent teeth. The main purpose of this bioactive material is to reduce the inflammation and aid in the formation of new tissue. ${ }^{3}$

In the past few decades, to resolve the limitations of calcium hydroxide material, a new bioactive material has been developed. Mineral trioxide aggregate (MTA) has been introduced at Loma Linda University in California in 1990. Numerous studies have reported that MTA yields promising results in clinical practice in many cases. Likely it can be used as obturating material, perforation repair, as pulp capping agent and apical barrier formation. It is biocompatible and bio active material. Composition of MTA consists of tricalcium silicate, tricalcium aluminate, tricalcium oxide and silicate oxide an inorganic material. The MTA gives an equivalent effect as calcium hydroxide on the pulp tissue. As the primary product in the setting reaction of MTA is calcium hydroxide.
Calcium ions released from MTA help in cell attachment and proliferation of pulpal cells. ${ }^{4}$ It also helps in the formation of hard tissues due to dentinogenesis and osteogenesis. The use of this material will lead to less inflammation compared to other material. In clinical practice, MTA shows high success rate due to its advantageous properties such as, sets in moisture which is beneficial in case of blood-filled procedures. High compressive strength $40 \mathrm{MPa}$ at 24 hours which increases up to $67.3 \mathrm{MPa}$ after 21 days. Good marginal adaptation of the MTA to the cavity margin is due to its setting expansion. Overall, with these advantages, there are some limitations such as discoloration of tooth, longer setting time, difficulty in manipulation and high cost. To overcome these disadvantages, other bioactive material with good clinical characteristics to serve all these functions has been developed such as Biodentin, calcium enriched mixture cement, enamel matrix derivative, bioceramics, bioactive glass, Theracal LC, etc. $^{5}$

Clinical success rate of vital pulp therapy depends on the histologic findings such as thickness of dentin barrier and formation of reparative dentin. The absence of clinical symptoms with long term follow up is most important criteria. $^{3}$

\section{METHODS}

\section{Research Question}

Is mineral trioxide an effective material for vital pulp therapy?

\section{Procedure}

Using, Preferred Reporting Items for Systematic Reviews and Meta-Analyses (PRISMA) guidelines statement, this systematic review was conducted. Reviewing all the abstracts and all texts, the studies are carefully chosen according to the inclusion and exclusion criteria and are reported below. None of the manuscript author was contacted during this process. Disagreements between authors were evaluated and the studies were eliminated through discussion among researchers until a consensus was reached.

\section{Included Data}

The systematic review is limited to the literature published in the English language without constraints of year. Randomized controlled trial; patient undergoing variable vital pulp therapy procedures; comparative study between MTA and other bioactive material; the evaluation of treatment results is seen on the basis of clinical symptoms and radiographic findings in the studies which show follow up at 1 year.

\section{Excluded Data}

In vivo and in vitro studies, which were performed on primary teeth and results showing histologic findings, review articles, studies which includes only one material. 


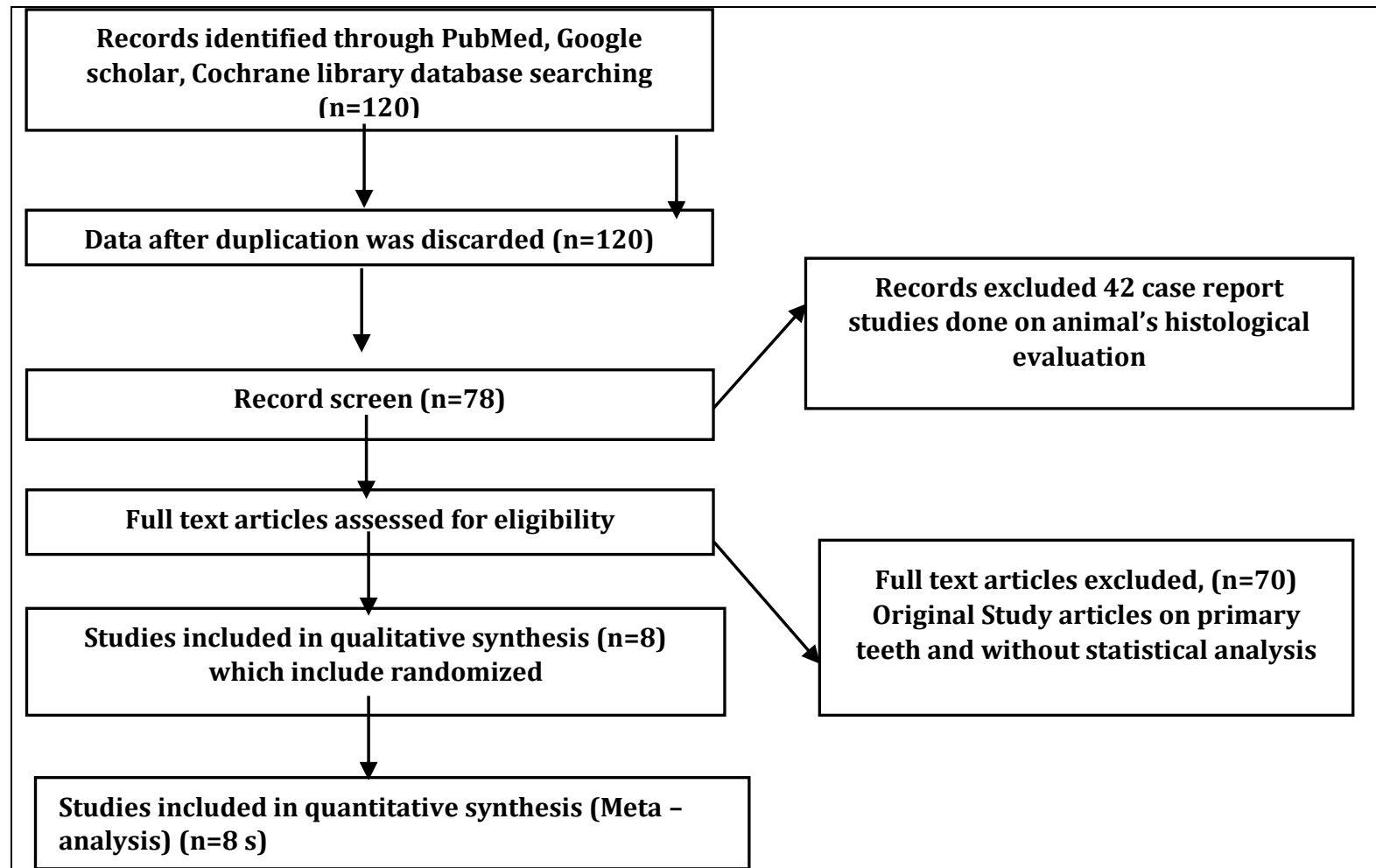

\begin{tabular}{|c|c|c|c|c|c|}
\hline \multicolumn{6}{|c|}{ Graph 1. Prisma Flow Diagram } \\
\hline Authors Name & No. of Sample & Type of Study & $\begin{array}{l}\text { Treatment } \\
\text { Performed }\end{array}$ & Result Outcome & Follow-up \\
\hline TJ Hilton et al (2013) & $\begin{array}{l}\text { 376-MTA (195) } \\
\text { Dycal (181) }\end{array}$ & Clinical trials & Direct pulp capping & $\begin{array}{c}\text { Failure rate - MTA-19.7 \% } \\
\text { Dycal - } 31.5 \%\end{array}$ & 2 Years \\
\hline Saeed Asgary - 2013 & $\begin{array}{l}\text { 413-PMTA (208) } \\
\text { PCEM (205) }\end{array}$ & Clinical trials & Pulpotomy & $\begin{array}{l}\text { PMTA } 98 \% \text { followed by } 95 \% \\
\text { PCEM } 97 \% \text { followed by } 92 \%\end{array}$ & 12 Months \\
\hline Lama Awawdeh - 2018 & 68 vital permanent teeth & Clinical trials & Vital pulp therapy & $\begin{array}{l}\text { MTA - } 93.5 \% \text { and Biodentine }-93.1 \% \text { at } 6 \text { months } \\
\text { MTA - } 100 \% \text { and Biodentine - } 96 \% \text { at } 1 \text { year }\end{array}$ & $\begin{array}{l}6 \text { months } \\
12 \text { months }\end{array}$ \\
\hline Eric Bonte - 2014 & $\begin{array}{l}\text { Children } \mathrm{n}=30 \\
\text { presenting non-vital } \\
\text { permanent immature } \\
\text { teeth }\end{array}$ & Clinical trails & Apexification & $\begin{array}{l}\text { It has been witnessed that calcific barrier formation } \\
\text { with the } \mathrm{CH} \text { group } 43.8 \% \text { and } 64.7 \% \text { with the MTA } \\
\text { group at the } \\
\text { 6-month examination. After } 12 \text { months }\end{array}$ & $\begin{array}{l}6 \text { months } \\
\text { And } 12 \text { months }\end{array}$ \\
\hline $\begin{array}{l}\text { Nuttaporn } \\
\text { Parinyaprom }\end{array}$ & $\begin{array}{c}59 \text { cariously exposed } \\
\text { human permanent } \\
\text { teeth } n=30 \text { MTA and } n= \\
29 \text { Biodentine }\end{array}$ & Clinical trials & Direct pulp capping & $\begin{array}{l}55 \text { patients of different age group were selected. } \\
\text { Among them } 27 \text { were treated with Pro Root MTA and } \\
28 \text { with Biodentine. Statistical analysis was done. } \\
\text { As per the follow up of } 6 \text { months and } 12 \text { months } \\
\text { results showed, the } 92.6 \% \text { positive response with } \\
\text { ProRoot MTA and } 96.4 \% \text { with Biodentine. }\end{array}$ & $\begin{array}{l}6 \text { months and } 12 \\
\text { months. }\end{array}$ \\
\hline Pairoj Linsuwanont-2016 & $\begin{array}{l}\text { pulpotomy was executed } \\
\text { in } 66 \text { vital permanent } \\
\text { teeth using MTA. Teeth } \\
\text { showing signs of } \\
\text { irreversible pulpitis and } \\
\text { peri-apical radiolucency } \\
\text { and carious pulp } \\
\text { exposure were included } \\
\text { in the study. The result } \\
\text { was evaluated on clinical } \\
\text { and radiographic finding } \\
\text { after } 12 \text { months. }\end{array}$ & Clinical trials & $\begin{array}{l}\text { Pulpotomy in } \\
\text { permanent teeth }\end{array}$ & $\begin{array}{l}\text { Follow up had been carried out between } 55 \text { patients } \\
\text { undergoing treatment. The patients between } 7-68 \\
\text { years old age (mean }=29 \text { years old). Period of } 62 \\
\text { month for follow-up period showed } 48 \text { teeth } \\
\text { successful outcomes (success rate }=87.3 \% \text { ). }\end{array}$ & 12 months \\
\hline Jamileh Ghoddusi-2012 & $\begin{array}{l}\text { In this study among the } \\
28 \text { patients, } 14 \text { patients of } \\
\text { group A are treated with } \\
\text { MTA and } 14 \text { patients are } \\
\text { treated with zinc-oxide } \\
\text { eugenol. } \\
\text { The patients are } \\
\text { evaluated } \\
\text { radiographically and } \\
\text { clinically. }\end{array}$ & Clinical trials & $\begin{array}{c}\text { Apexogenesis } \\
\text { (pulpotomy) }\end{array}$ & $\begin{array}{c}\text { In the beginning of this study } 8.3 \% \\
\text { of roots in Group } \\
\text { A and } 46.7 \% \\
\text { in Group B had } \\
\text { a blunderbuss apex. } \\
\text { s } \\
\text { After three months, } 25 \% \text { of roots in } \\
\text { Group A and } 33.3 \% \\
\text { In Group B were closed. Between } 6 \text { and } 12 \text { months, } \\
58.3 \% \text { of roots in Group A } \\
\text { and } 75 \% \text { in Group B } \\
\text { had closed apices. There was no significant difference } \\
\text { between the groups (P = 0.28). }\end{array}$ & $\begin{array}{l}\text { Follow up 3,6 and } 12 \\
\text { months. }\end{array}$ \\
\hline
\end{tabular}




\section{Data Extraction and Quality Assessment}

The primarily used data for this review were extracted by analyzing the title and reading abstract of various clinical studies. The full text was read for proper understanding as the results were unclear. The authors, by their own, evaluated the studies and discussed the results until a decision was reached by consensus. Data was created by tabulating authors name, publication year, sample size, material used, treatment performed, clinical and radiographical examination, follow-up period and success rate. Studies included in the table are all clinical trials.

\section{DISCUSSION}

The treatment of teeth having carious pulp exposure is the problematic issue. According to many authors, there are two treatment options which gives better results and sustains the longevity of tooth; vital pulp therapy and root canal procedures can be performed depending on clinical scenario. Both the treatments have their individual pros and cons. ${ }^{5}$

Vital pulp therapy aids in the formation of secondary dentin and reparative dentin in presence to biologic and pathologic stimuli, and also helps in sealing the pulp and prevent bacterial entry and leakage. The main function of pulp is formation of dentin; it helps to keep dentin in moisture and nourished state and also helps to increase the strength and hardness of dentin. ${ }^{6}$ The nonvital tooth required $2.5 \mathrm{~N}$ greater force to sustain against masticatory force when compared to vital tooth. The criteria for choosing vital pulp therapy is based on a number of factors; such as, evaluation regarding patient's symptoms, after performing various diagnostic test, patient age and size of exposed area. ${ }^{7}$

The success of any treatment procedure not only depend on the coating of the exposed area, but all the factors need to be considered. The material provides good marginal seal, high compressive strength, nontoxic effect on pulp cells and possess high remineralization capacity. Though calcium hydroxide $(\mathrm{CH})$ is considered as gold standard material in these procedures. According to many studies it has been observed that it has inferior results as compared to recently developed pulp capping materials. While treating exposed pulp with $\mathrm{CH}$ and Biodentine in Tran et al. study concluded that structures formed by $\mathrm{CH}$ shows many inclusions known as tunnel defects. These types of defects lead to create unwanted areas and gives entry to the microorganisms and started further pulpal infection. Nowadays, MTA has been considered as material of choice for pulp capping due to its increased regenerative potential of pulp tissue. There are numerous case reports and studies which noted the successful results of MTA in pulpotomy in primary or immature permanent teeth. ${ }^{8}$ The occurrence of post-operative pain and the clinical and radiographic outcomes are the contributing factors while considering root canal treatment as last alterative option.

This is the first systematic review which is based on randomized controlled trials of vital pulp therapy of carious pulp exposures in permanent teeth using MTA. In the present systematic review, 8 randomized controlled trials were included reporting comparisons between MTA and with other bioactive materials among different vital pulp therapy procedures.
Various studies conducted have stated following results using MTA as vital pulp therapy.

Saeed Asgary et al. in 2011 stated that there was no significant difference in the favourable outcomes of permanent molar teeth with irreversible pulpitis undergoing pulpotomy using calcium-enriched mixture (CEM) cement or MTA. ${ }^{9}$ It is also stated that the success rate of vital pulp therapy depends on the sealing ability of materials. CEM prevents microleakage and has a sealing ability superior to Intermediate Restorative material (IRM) and comparable to MTA. ${ }^{1}$

Jamileh Ghoddusi et al. in 2012 stated that zinc oxide eugenol (ZOE) and MTA are suitable materials for cervical pulpotomy. MTA can be used with assurance on cases diagnosed as irreversible pulpitis, as it is associated with high cure rates in these cases. A clearer and more decisive conclusion regarding the success of MTA treatment in immature teeth and their subsequent development would require a longer follow-up period and histological examinations. ${ }^{10}$

On the basis of comparative study of Erica Bonte in 2014 apexogenesis can be possible with using both the material that is MTA and $\mathrm{CH}$ in immature teeth. According to this randomized control trial, it has been observed that there is no statically significant difference seen in case of apical closure at 6- and 12-months' period. Regardless, MTA has better clinical outcome. In case of periapical healing after evaluation of clinical findings and radiographs in all the treated cases with both materials gave good results. But superior results were obtained with MTA apexification cases. This study also focused on important fact such as increase of cervical fracture after frequent and extended use of $\mathrm{CH}$ as root canal filling. While chances of fracture were observed with MTA. ${ }^{3}$

Above all these reasons, it has been suggested to prefer MTA procedures as treatment options with immature necrotic teeth especially in the clinical scenario with large open apices and apical periodontitis over $\mathrm{CH}$ apexification. Survival rate of MTA treated teeth on long term follow up was not given in this study. 11

TJ Hilton in 2013 conducted study which is based on randomized control trial comparing calcium hydroxide and MTA for direct pulp capping. In his study, he stated that MTA has better results for direct pulp capping due to its superior sealing ability. ${ }^{12}$

Nuttaporn Parinyaprom in 2017 conducted clinical trials comparing ProRoot MTA and Biodentine on permanent teeth of 6 - 18 years old patient as pulp capping agent due to carious exposure of the pulp. The results showed no clinically significant difference. Due to its same chemical composition, the results for direct pulp capping is superior. So, the study also compared the discoloration of teeth as criteria for comparison. He stated that ProRoot MTA shows more discoloration as compared to Biodentine because it contains different radiopacifier i.e., bismuth oxide. ${ }^{13}$

Pairoj Linsuwanont in 2016 conducted the retrospective study in vital permanent teeth in which pulpotomy procedures were carried out after carious exposure of pulp. The author claimed that MTA has successful result in the pulpotomy cases. On the basis of histological study, he stated that dentin bridge was formed, and status of radicular pulp was also normal and healthy. Periapical radiolucency and clinical signs and symptoms also reduced after 1 month and 3 months. ${ }^{14}$ 
Minju Songin 2015 carried out a randomized control trial for permanent teeth using ProRoot MTA and Endocem as direct pulp capping agent. According this study, both the materials provide superior results in direct pulp capping procedure. No significant difference was observed.

Multiple materials have been utilised in vital pulp therapy as pulp capping agents. Various authors in their studies compared these agents with MTA and showed that MTA being the superior material and gives beneficial results while using as vital pulp therapy.

\section{CONCLUSIONS}

MTA is a promising bioactive material. Preservation of tooth vitality is of prime importance. Various agents have been tried. MTA, due to presence of various active ingredients, helps in regeneration of pulpal tissue. MTA must be utilised in direct and indirect pulp therapy.

Financial or other competing interests: None.

Disclosure forms provided by the authors are available with the full text of this article at jemds.com.

\section{REFERENCES}

[1] Asgary S, Eghbal MJ. Treatment outcomes of pulpotomy in permanent molars with irreversible pulpitis using biomaterials: a multi-center randomized controlled trial. Acta Odontol Scand 2013;71(1):130-6.

[2] Beslot-Neveu A, Bonte E, Baune B, et al. Mineral trioxyde aggregate versus calcium hydroxide in apexification of nonvital immature teeth: study protocol for a randomized controlled trial. Trials 2011;12(1):174.

[3] Bonte E, Beslot A, Boukpessi T, et al. MTA versus Ca $(\mathrm{OH})_{2}$ in apexification of non-vital immature permanent teeth: a randomized clinical trial comparison. Clin Oral Investig 2015;19(6):1381-8.

[4] Zhu C, Ju B, Ni R. Clinical outcome of direct pulp capping with MTA or calcium hydroxide: a systematic review and meta-analysis. Int J Clin Exp Med 2015;8(10):17055-60.
[5] Hegde S, Sowmya B, Mathew S, et al. Clinical evaluation of mineral trioxide aggregate and biodentine as direct pulp capping agents in carious teeth. J Conserv Dent 2017;20(2):91-5.

[6] Awawdeh L, Al-Qudah A, Hamouri H, et al. Outcomes of vital pulp therapy using mineral trioxide aggregate or biodentine: a prospective randomized clinical trial. J Endod 2018;44(11):1603-9.

[7] Nowicka A, Lipski M, Parafiniuk M, et al. Response of human dental pulp capped with biodentine and mineral trioxide aggregate. J Endod 2013;39(6):743-7.

[8] Malekafzali B, Shekarchi F, Asgary S. Treatment outcomes of pulpotomy in primary molars using two endodontic biomaterials. A 2-year randomised clinical trial. Eur J Paediatr Dent 2011;12(3):189-93.

[9] Nosrat A, Seifi A, Asgary S. Pulpotomy in caries-exposed immature permanent molars using calcium-enriched mixture cement or mineral trioxide aggregate: a randomized clinical trial. Int J Paediatr Dent 2013;23(1):56-63.

[10] Ghoddusi J, Shahrami F, Alizadeh M, et al. Clinical and radiographic evaluation of vital pulp therapy in open apex teeth with MTA and ZOE. N Y State Dent J 2012;78(3):348.

[11] Sawicki LE, Pameijer CH, Emerich KA, et al. Histological evaluation of mineral trioxide aggregate and calcium hydroxide in direct pulp capping of human immature permanent teeth. Am J Dent 2008;21(4):262-6.

[12] Hilton TJ, Ferracane JL, Mancl L, et al. Comparison of $\mathrm{CaOH}$ with MTA for direct pulp capping: a PBRN randomized clinical trial. Journal of Dental Research 2013;92(7 Suppl):S16-22.

[13] Parinyaprom N, Nirunsittirat A, Chuveera P, et al. Outcomes of direct pulp capping by using either ProRoot Mineral Trioxide Aggregate or Biodentine in permanent teeth with carious pulp exposure in 6-to 18-year-old patients: a randomized controlled trial. J Endod 2018;44(3):341-8.

[14] Linsuwanont P, Wimonsutthikul K, Pothimoke U, et al. Treatment outcomes of mineral trioxide aggregate pulpotomy in vital permanent teeth with carious pulp exposure: the retrospective study. J Endod 2017;43(2):225-30. 